\title{
GURU DAN KOMPETENSI KEPRIBADIAN
}

\section{Oleh :}

\section{Purwanti $^{1}$}

\begin{abstract}
Abstrak: Guru merupakan salah satu komponen terpenting dalam dunia pendidikan. Ruh pendidikan sesungguhnya terletak dipundak guru. Bahkan, baik buruknya atau berhasil tidaknya pendidikan hakikatnya ada di tangan guru. Sebab, sosok guru memiliki peranan yang strategis dalam "mengukir" peserta didik menjadi pandai, cerdas, terampil, bermoral dan berpengetahuan luas. Sebagai tenaga edukatif dalam lingkup sekolah, guru harus memiliki kompetensikompetensi dasar kependidikan. Sebab dalam interaksi pembelajaran peserta didik, seorang guru harus bisa melakukan demonstrasi yang hidup dan menyenangkan bagi peserta didik. Kemampuan dasar yang harus dimiliki guru adalah yang sesuai dengan nilai dan norma yang berlaku. Misalnya, berkepribadian dewasa, mandiri dan bertanggung jawab terutama secara moral sehingga dapat dijadikan teladan bagi peserta didiknya. Kompetensi yang dimaksud adalah kompetensi kepribadian.
\end{abstract}

Kata Kunci: Guru, kompetensi, kepribadian.

\section{Pendahuluan}

Guru sebagai salah satu ujung tombak dalam proses pendidikan dituntut memiliki kemampuan profesionalitas yang tinggi sehingga harus selalu mengikuti perkembangan ilmu pengetahuan dan teknologi, serta tuntutan masyarakat yang terus menerus berubah sesuai dengan perkembangan zaman. Peningkatan kemampuan tersebut dapat dilakukan oleh guru itu sendiri melalui kegiatan yang mendukung peningkatan pengetahuan dengan memanfaatkan sumber-sumber yang ada, dapat melakukan kegitan seminar, simposium dan penelitian, oleh karenanya guru tidak hanya dituntut untuk melaksanakan tugas peranannya sebagai guru tetapi harus terus-menerus meningkatkan kompetensinya, terutama kompetensi kepribadian.

Tuntutan akan kepribadian kadang dirasakan lebih berat dibandingkan profesi lainnya. Ungkapan yang sering didengar: "Guru adalah yang dapat digugu dan ditiru" sering dijadikan panutan oleh masyarakat, oleh

${ }^{1}$ Purwanti : adalah dosen Jurusan Ilmu Pendidikan FKIP Untan 
karena itu guru harus mengenal nilai-nilai yang ada di masyarakat tempat di mana guru tersebut tinggal atau mengajar. Sebagai teladan guru harus memiliki kepribadian yang diidolakan, kehidupannya adalah figur yang paripurna, itulah kesan guru yang diharapkan masyarakat..

Kepribadian yang dimiliki guru sangat menentukan tinggi rendahnya kewibawaan seorang guru dalam pandangan peserta didik atau anggota masyarakat disekitarnya, seperti yang telah dikemukakan oleh Syah (2005: 225-226):

Kepribadian itulah yang akan menentukan apakah ia menjadi pendidik dan pembina yang baik bagi anak didiknya, ataukah akan menjadi perusak atau penghancur bagi masa depan anak didiknya terutama bagi anak didik yang masih kecil (tingkat dasar) dan mereka yang sedang mengalami kegoncangan jiwa (tingkat menengah).

Wibawa dan citra yang dimiliki guru di mata peserta didik dan anggota masyarakat tidak selamanya dapat dijaga oleh seseorang yang berprofesi guru. Wibawa dan citra guru masih banyak dicemarkan oleh beberapa guru yang kurang bertanggungjawab. Pada media masa baik cetak maupun elektronik banyak diberitakan guru-guru yang bertindak amoral, yang seharusnya tidak dilakukan oleh seorang yang berprofesi guru, seperti yang diberitakan koran lokal di Kalimantan Barat terjadinya pelecehan seksual yang dilakukan guru di sekolah dasar, dan terjadi peristiwa guru memukul anak didiknya (Metro, 20 Juli 2010). Laporan Komisi Perlindungan Anak Indonesia bahwa dalam kurun waktu Januari hingga Juni 2009 kekerasan terhadap anak mencapai 6.226 kasus, dan sebanyak 11,3\% dilakukan oleh guru. Kasus-kasus tersebut berupa kekerasan fisik, pelecehan seksual dan bullying. Penelitian Mulyana (2001:266) menemukan bahwa: "Guru lebih berorientasi pada isi ketimbang pada siswa, pada situasi ini siswa sebenarnya tidak menghendaki belajar, tetapi mereka mananggapi arahan dan pengawasan yang kuat." Peran guru dalam strategi ini lebih menekankan pada penyampaian sejumlah materi pengajaran sesuai dengan kurikulum yang ditargetkan sedangkan kebutuhan-kebutuhan siswa cenderung terabaikan.

Keakraban hubungan guru dengan anak didik ditentukan oleh kepribadian dari guru tersebut. Cerminan kepribadian guru ditentukan oleh sikap dan perbuatan guru dalam membina dan membimbing peserta didik. Menurut Mikeljohn dalam Djamarah, (2000:41): "Seorang guru yang sejati atau mulia apabila guru tersebut sudah menjadikan dirinya sebagai bagian dari peserta didik dan berusaha memahami apa yang dikatakan peserta didiknya." Guru yang disenangi peserta didik adalah guru yang mampu 
memahami kesulitan peserta didik dalam masalah belajar maupun di luar belajar yang dapat menghambat aktifitas belajar peserta didik.

Faktor terpenting bagi keberhasilan peserta didik dalam pembelajaran adalah kepribadian yang ada pada guru. Hal ini ditunjukkan dari hasil penelitian Supriadi (2007), menemukan bahwa, "kepribadian guru memiliki pengaruh yang lebih dominan terhadap prestasi belajar PKn dibandingkan variabel motivasi belajar, dengan demikian semakin tinggi intensitas persepsi siswa mengenai kepribadian guru dapat dipastikan memberikan

Penelitian Muray dalam Hakim (2012:4) menyatakan bahwa "ranah kepribadian mempengaruhi perilaku guru dalam penggunaan metode yang beragam, misalnya interaksi dengan siswa, mengutamakan pengalaman belajar siswa." Sejalan dengan Muray penelitian Coats dalam Hakim (2012:14) yang menemukan bahwa $61,5 \%$ dari 42.810 siswa beranggapan bahwa karisma guru merupakan faktor paling signifikan keefektifan guru dalam mengajar.

\section{Konsep Kompetensi Guru}

Kompetensi dapat dipahami sebagai kecakapan atau kemampuan. Rusman (2010:70) mengatakan: "Kompetensi merupakan perilaku rasional untuk mencapai tujuan yang dipersyaratkan." Goncsi (2004:4) berpendapat: "The capacity to perfomspecific activities will always entail same combination of knowledge/skills/disposition/values which when analysed."

Banyak orang menafsirkan kompetensi merupakan tingkah laku yang diperlukan seseorang untuk melaksanakan tugasnya dengan baik. Kompetensi yang dimiliki seseorang akan dapat memberikan ciri tindakan, tingkah laku, serta kecakapan dalam melaksanakan pekerjaannya. Beberapa orang menafsirkan kompetensi sebagai satu kesatuan tingkah laku yang diperlukan seseorang untuk menjalankan tugasnya dengan baik. Seperti apa yang dikatakan Cooper (1986:4): "Wilayah kompetensi seorang guru terdiri dari pengetahuan dan keterampilan dalam pembelajaran (kompetensi pedagogik), sikap (kompetensi kepribadian), dan penguasaan bidang studi (kompetensi profesional)."

Uno (2007:62) berpendapat, "kompetensi adalah kekuatan mental dan fisik untuk melakukan tugas atau keterampilan yang dipelajari melalui latihan dan praktik." Sofo (1999:123) dalam Rastodio (2009) mengemukakan "Acompetency is composed of skill, knowledge, and attitude, but in particular the consistent applications of those skill, knowledge, and attitude to the standard of performance required in employment." 
Kompetensi memiliki lima karakteristik antara lain:

a. Motif, yaitu dorongan yang ada pada diri seseorang yang menyebabkan seseorang melakukan suatu perbuatan.

b. Sifat, merupakan karakteristik seseorang dalam menanggapi suatu situasi atau informasi secara konsisten. Contoh penglihatan yang baik adalah kompetensi fisik yang diperlukan bagi seorang yang berprofesi pilot. Kontrol diri secara emosional adalah kompetensi yang harus dimiliki oleh seseorang yang berprofesi guru.

c. Konsep diri. Konsep diri menggambarkan pengetahuan tentang diri sendiri yang mencakup konsep diri jasmaniah, diri sosial, dan diri spiritual. Konsep diri jasmaniah mengacu pada keadaan fisik, fungsi dan penampilan fisik. Pengetahuan, yaitu informasi yang dimiliki seseorang dalam bidang tertentu. Misalnya: Pengetahuan seorang guru tentang berbagai macam metode pembelajaran.

d. Keterampilan berarti kemampuan untuk mengoperasikan suatu pekerjaan baik secara fisik maupun mental secara mudah dan cermat yang membutuhkan kemampuan dasar. Contoh pekerjaan secara fisik adalah keterampilan membuat alat peraga untuk pembelajaran sedangkan keterampilan mental adalah kemampuan memecahkan masalah. Dari pendapat yang telah dikemukakan dapat ditarik kesimpulan tentang kompetensi yaitu suatu kemampuan yang dapat menggambarkan potensi, pengetahuan, keterampilan, dan yang ada hubungannya dengan profesi tertentu sehingga dapat diaktualisasikan dalam bentuk unjuk kerja.

Jika digabungkan dengan sebuah profesi misalnya guru, maka kompetensi guru mengandung arti kemampuan yang dimiliki guru untuk melakukan kewajiban-kewajiban dengan penuh tanggungjawab dan memiliki kelayakan atau kemampuan dan memiliki wewenang guru dalam menjalankan profesi keguruannya. Seperti yang dikatakan oleh Kusnandar (2007:51), pengertian kompetensi guru adalah "suatu hal yang menggambarkan kualifikasi dan kemampuan seseorang baik yang kulitatif maupun yang kuantitatif." Sejalan dengan pendapat ini, Majid (2005:5), mengatakan "kompetensi guru dapat dimaknai sebagai tindakan inteligen penuh tanggungjawab yang harus dimiliki seseorang sebagai syarat untuk dianggap mampu untuk melaksanakan tugas-tugas dalam pekerjaan tertentu."

Sementara itu menurut kebijakan pendidikan nasional, rumusan yang telah dibuat pemerintah tentang empat jenis kompetensi guru yang dicantumkan pada Penjelasan Peraturan Pemerintah No 19 Tahun 2005 tentang Standar Nasional Pendidikan, antara lain:

Kompetensi pedagogik merupakan kemampuan guru dalam mengelola peserta didik antara lain : (1) memahami tentang wawasan atau landasan 
kependidikan; (2) memahami peserta didik; (3) mengembangkan kurikulum/ silabus; (4) merancang proses pembelajaran; (5) melaksanaan pembelajaran yang mendidik dan dialogis; (6) melakukan evaluasi belajar; (7) mengembangkan siswa agar dapat mengaktualisasikan semua potensi yang ada.

Kompetensi kepribadian antara lain memiliki kepribadian: (1) kemantapan dalam bertindak, (2) kestabilan dalam emosi, (3) kedewasaan, (4) kearifan dan kebijaksanaan, (5) memiliki kewibawaan, (6) menunjukkan akhlak mulia, (7) menunjukkan keteladanan bagi peserta didik dan lingkungan masyarakat; (8) mampu menilai kinerja sendiri, dan (9) mampu mengembangkan diri secara berkelanjutan.

Kompetensi sosial adalah kemampuan seorang pendidik yang merupakan bagian dari masyarakat supaya: (1) mampu melakukan komunikasi secara lisan dan tulisan, (2) mampu memanfaatkan teknologi komunikasi dan informasi secara berdayaguna, (3) mampu bergaul secara efektif dengan siapapun baik di institusi pendidikan atau di luar institusi pendidikan (4) mampu bergaul dengan masyarakat secara santun.

Kompetensi profesional adalah kemampuan seorang pendidik dalam menguasai materi pembelajaran secara luas dan mendalam antara lain tentang: (1) konsep, struktur, dan metoda keilmuan/teknologi/seni yang menaungi/koheren dengan materi ajar, (2) materi ajar yang termaktup dalam kurikulum sekolah, (3) hubungan antar mata pelajaran (4) konsep-konsep keilmuan yang diterapkan dalam kehidupan sehari-hari, dan (5) kompetisi dengan cara profesional.

Secara esensial pendapat di atas tidak terdapat perbedaan yang prinsip. Perbedaannya hanya terletak pada pengelompokan masing-masing aspek dan indikatornya. Dengan tidak mengurangi pentingnya salah satu kompetensi yang harus dimiliki guru, kompetensi kepribadian hendaknya mendapatkan proporsi lebih karena kompetensi ini ada hubungannya dengan idealisme dan kemampuan guru, agar dapat memahami dirinya sendiri sebagai seorang pendidik. Kompetensi ini sangat dibutuhkan karena berimplikasi langsung pada kehidupan sehari-hari dan dapat dipantau langsung oleh siswa. Dengan demikian kompetensi kepribadian harus benarbenar dimiliki oleh seorang calon guru.

\section{Konsep Kompetensi Kepribadian Guru}

Karakteristik kepribadian guru sangat berpengaruh terhadap keberhasilan pembelajaran yang berdampak pada keberhasilan pengembangan sumber daya manusia. Keteladanan yang dapat ditunjukkan guru apabila guru tersebut memiliki kepribadian yang mantap yang dapat 
mempengaruhi peserta didik dan masyarakat yang ada di sekelilingnya sehingga guru merupakan sosok yang dapat "digugu" dan "ditiru." Faktor yang terpenting dalam mencapai tujuan pembelajaran bagi peserta didik adalah kepribadian guru yang mantap, sesuai dengan apa yang diuraikan oleh Syah (2000:225-226) :

Kepribadian itulah yang akan menentukan apakah ia menjadi pendidik dan pembina yang baik bagi anak didiknya, ataukah akan menjadi perusak atau penghancur bagi masa depan anak didiknya terutama bagi anak didik yang masih kecil (tingkat dasar) dan mereka yang sedang mengalami kegoncangan jiwa (tingkat menengah).

Raimond Bernad Cattel (dalam Raosidi, 2012) mengemukakan, "kepribadian adalah sesuatu yang memungkinkan untuk memprediksi tentang apa yang dikerjakan seseorang dalam saat tertentu, mencakup semua tingkah laku individu baik yang terbuka (lahiriyah) maupun yang tersembunyi."

Kepribadian pada prinsipnya adalah kesatuan atau susunan antara aspek mental seperti, pikiran, perasaan, dengan aspek perilaku yang merupakan perbuatan nyata, aspek-aspek ini berhubungan antara satu dengan lainnya secara fungsional dalam individu sehingga bertingkah laku secara tetap dan khas. (Syah, 2005:205).

Schermerhon, dkk mengemukakan dalam Simbolon (2008:62), "Personality represent the overall profile, or combinationof characteristics, the captures the uniquenature of the person as the reats and interacts with other." Kepribadian merepresentasikan keseluruhan profil atau kombinasi karakteristik dan memiliki keunikan secara alami dari diri seseorang sebagai reaksi dari interaksinya dengan orang lain.

Guru pada dasarnya memegang peranan yang amat sentral dalam keseluruhan proses belajar mengajar. Guru dituntut harus mampu mewujudkan perilaku mengajar secara tepat agar menjadi perilaku belajar yang efektif dalam diri siswa atau pelajar.

Surya, (2004:57) berpendapat bahwa karakteristik yang harus dimiliki pengajar untuk mewujudkan perilaku mengajar adalah:

a. Memiliki minat yang besar terhadap pelajaran dan mata pelajaran yang diajarkan.

b. Memiliki kesabaran, keakraban untuk membangkitkan motivasi belajar siswa.

c. Memiliki kemampuan untuk menerapkan metode yang bervariasi yang sesuai dengan psikologi siswa.

d. Berpenampilan rapih dan sopan.

e. Memiliki sikap terbuka dan luwes dalam metode dan teknik. 
f. Menguasai materi pelajaran yang akan diajarkan.

Dari uraian di atas menjadi jelas bahwa kepribadian yang dimiliki oleh seorang guru itu akan berpengaruh terhadap kelangsungan belajar siswa baik langsung maupun secara tidak langsung. Maka dari itu bagi seorang guru setidaknya mempunyai kepribadian yang menarik sehingga dapat di contoh dan diteladani oleh para siswanya. Menurut Irsyad (2008:7): "Guru senantiasa harus menjadi contoh bagi peserta didiknya, perilaku guru harus mencerminkan ucapannya dan tidak diperkenankan bersikap "jarkoni" alias biso ngajar ora iso nglakoni (bisa ngajar tidak bisa melaksanakan)."

Jika digabungkan pengertian kompetensi dengan kepribadian menurut Mulyasa (2003:38) adalah, "semua keterampilan yang ada, pengetahuan dan kemampuan yang dikuasai oleh seseorang yang telah menjadi bagian dari dirinya sehingga ia dapat melaksanakan perbuatanperbuatan yang bersifat kognitif, memiliki sifat afektif dan psikomotorik dengan baik.".

Kompetensi kepribadian yang dimuat dalam standar nasional pendidikan meliputi, (1) mempunyai kepribadian yang memiliki kebanggaan sebagai pendidik, berusaha konsisten dalam melakukan tindakan sesuai dengan norma yang berlaku (2) menunjukkan kepribadian yang dewasa, dengan ciri-ciri, berusaha menampilkan kemandirian dalam melakukan tindakan sebagai pendidik yang mempunyai etos kerja tinggi. (3) berusaha menunjukkan kepribadian yang arif, dengan ciri-ciri melakukan tindakan yang bermanfaat bagi anak didik, sekolah dan masyarakat. Memiliki keterbukaan dalam bertindak. (4) Menunjukkan kepribadian yang berwibawa, disegani dan berpengaruh positif terhadap peserta didik. (5) Memiliki akhlak mulia dan menjadi teladan, dengan cirri-ciri menunjukkan perilaku sesuai dengan norma religius dengan menunjukkan keimanan dan ketaqwaan, berlaku jujur, melakukan pekerjaan dengan ikhlas dan suka menolong sehingga dapat menjadi teladan bagi murid..

Pada saat ini banyak terjadi kasus seorang guru yang memiliki kemampuan pada kompetensi pedagogis dan profesional dan bidang studi yang menjadi tanggungjawabnya, tetapi dalam pelaksanaan pembelajaran menujukkan ketidaksenangan siswa karena hal ini mungkin disebabkan tidak adanya keakraban antara siswa dan guru baik di dalam maupun di luar kelas. Peningkatan kompetensi kepribadian guru masih kurang diperhatikan oleh pemerintah. Pemerintah lebih mengutamakan peningkatan kemampuan pedagogis dan profesional guru, baik melalui workshop, penataran, pelatihan, memanfaatkan musyawarah guru mata pelajaran (MGMP). 


\section{Aspek-aspek dan Indikator Kompetensi Kepribadian Guru}

\section{a. Berakhlak mulia, arif bijaksana dan berperilaku santun}

Imam Gazali menyebutkan ciri-ciri orang yang berakhlak mulia adalah: Beberapa ciri akhlak mulia, diantaranya merasa malu untuk melakukan keburukan, tidak senang menyakiti, berkelakuan baik, dan berkata jujur. Selain itu, tidak banyak bicara, banyak berkarya, sedikit melakukan kesalahan (yang berulang), tidak banyak melakukan intervensi, tenang, sabar, suka bersyukur, ridha akan realitas kehidupan (pahit maupun manis), bijaksana, lemah-lembut, pandai menjaga kesucian dan harga diri, penyayang, tidak senang melaknati sesuatu atau orang lain (Republika:2012).

Guru yang berakhlak mulia mengaku dirinya sebagai hamba Allah, menunjukkan ketaatan kepada aturan agama yang dipeluknya, dan syariatsyariat agama selalu dijalankan sesuai dengan ajaran yang berlaku dalam agamanya. Ia adalah sosok religius yang selalu berupaya menjalankan syariat-syariat sesuai ajaran agama yang dianut. Guru sebagai makhluk sosial dan makhluk individu tidak dapat hidup tanpa orang lain karena sejak lahir hingga tua nanti akan selalu berhubungan dengan individu lain, dengan istilah lain guru selalu melakukan relasi interpersonal. Aktivitas individu dalam relasi interpersonal ini diistilahkan dengan perilaku sosial. Aktivitas individu yang dihasilkan dapat berdasarkan naluri semata atau melalui kegiatan pembelajaran.

\section{b. Berkepribadian stabil, mantap dan disiplin}

Salah satu poin penting yang menjadi ciri kepribadian stabil adalah mampu menyesuaikan diri dengan berbagai perubahan dan pola kehidupan. Selain itu, perilakunya selalu positif, baik di rumah, sekolah, maupun lingkungan sosialnya. Tak heran jika guru mudah diterima di lingkungan mana pun. Guru merupakan sosok penegak disiplin, yang memiliki keluwesan dan kebijaksanaan, tidak kaku dan tidak konservatif. Dengan penuh kesadaran dan tulus ikhlas guru senantiasa patuh terhadap aturan yang ada, ketentuan yang berlaku, kesepakatan yang telah dibuat bersama dan prosedur serta instruksi kerja yang merupakan bentuk penghargaan kepada orang lain.

Guru ideal adalah yang berkepribadian stabil. Salah satu poin penting yang menjadi ciri kepribadian stabil adalah mampu menyesuaikan diri dengan berbagai perubahan dan pola kehidupan, selain itu perilakunya selalu positif baik di rumah, sekolah, maupun lingkungan sosialnya. Tak heran jika guru mudah diterima di lingkungan manapun, kepercayaan selalu dijaga yang 
dapat membuat guru memiliki semangat untuk memajukan bangsa dan negaranya. Keberhasilan guru dalam memimpin tidak hanya dilihat dari keberhasilan guru memimpin para siswanya tetapi juga keluarga dan masyarakat yang ada di sekitarnya. Guru profesional selalu berupaya agar pemahaman visi, misi, tujuan dan target selalu ada keterkaitan.

Tanggung jawab terkait erat dengan kompetensi akhlak mulia, kearifan dan bijaksana, mantap, kewibawaan, stabilitas kepribadian, kejujuran untuk mengatakan kebenaran atau menyesuaikan kata-kata dengan realitas.

Kemandirian seorang guru merupakan tuntutan sebagian dari keprofesionalan sebagai seorang guru. Kemandirian ini penting dalam mengaktualisasi diri sebagai seorang guru yang baik, seperti dikatakan Mouly (1973:106) bahwa: "Aktualisasi diri sebagian besar ditentukan oleh diri sendiri. Guru merupakan bagian dari sebuah sistem yaitu sistem pendidikan dan pembelajaran." Sebagai bagian dari sebuah sistem guru dituntut untuk mampu bekerja sama dengan bagian lain dari sistem tersebut. Seperti dijelaskan oleh Slavin (1984:156) bahwa: "Seseorang akan menghargai orang lain yang keberhasilannya mampu dinikmati oleh orang lain juga." Penjelasan ini memberikan pengertian bahwa keberhasilan kelompok akan lebih dihargai daripada keberhasilan individu. Hal ini disebabkan karena keberhasilan kelompok, selain berhasil dalam prestasi juga berhasil dalam bekerjasama.

\section{c. Jujur, objektif dan bertanggungjawab}

Integritas seorang guru profesional memiliki kemampuan menilai secara obyektif, memiliki sifat jujur dan tanggungjawab terhadap pekerjaannya, ucapan dan perilakunya dan memiliki tanggungjawab sosial. Sifat konsistensi guru perlu dijaga yang berarti sanggup mengatakan sesuatu itu benar, dan yang salah itu salah walaupun menyakitkan. Guru harus dapat mengutamakan kebenaran di atas kepentingan pribadi. Informasi yang diberikan hendaknya yang jujur karena akan menentukan keberhasilan siswa. Informasi yang dibutuhkan siswa harus diberikan secara benar karena informasi itu merupakan stimulus yang berguna bagi siswa. Informasi yang disampaikan guru apabila tidak benar akan membuat siswa terjebak dalam informasi yang tidak bermanfaat, oleh karena itu kejujuran guru dalam menyampaikan informasi sangat diperlukan bagi siswa, seperti yang diungkapkan oleh Tilaar (2000:41) "Kesalahan dalam mengerti bahan akan menyebabkan peserta didik mengerti secara salah atau terjadi salah konsep." 


\section{d. Berwibawa dan patut diteladani}

Guru profesional harus memiliki semua sisi kehidupan yang patut diteladani (Ing ngarso sung tulodo), yaitu teladan bagi peserta didik, orang tua murid, keluarga dan masyarakat sekelilingnya. Kewibawaan yang dimiliki guru bukanlah kekuasaan, pancaran kepribadiannya mampu mempengaruhi masyarakat sekelilingnya secara positif. Seorang guru harus mampu untuk menjadi teladan tidak hanya bagi muridnya tetapi keluarga, lingkungan dan masyarakat sekitarnya. Menurut Manurung (2008:511), "guru yang berwibawa berarti guru yang dapat membuat siswanya terpengaruh oleh tutur katanya, pengajarannya, patuh kepada nasehatnya, dan mampu menjadi magnet bagi siswanya sehingga siswanya akan terkesima dan tekun menyimak pengajarannya."

Jam kerja yang harus dilakukan guru adalah 24 jam. Tanggungjawab moral dan hati nurani sangat didambakan oleh masyarakat agar aktif dalam setiap kegiatan sosial, budaya dan ekonomi di lingkungannya. Guru dituntut sebagai sosok yang berperan utama dalam mewujudkan kemajuan pendidikan dalam keluarga dan lingkungan sekitarnya. Faktor penting dalam kompetensi ini adalah memiliki akhlak mulia, bertindak secara arif dan bijaksana, berkepribadian mantap, memiliki kewibawaan, keteladanan, mampu mengembangkan diri secara terus menerus, pandai bergaul, santun dalam bertindak dan memiliki sifat kooperatif.

\section{e. Empati}

Empati berperan penting dalam pembelajaran. Seorang guru perlu memiliki rasa empati yang tinggi terhadap muridnya karena dapat meningkatkan kualitas hubungan antara guru dan murid. Melalui empati seorang guru dapat memahami kondisi muridnya sehingga dapat membantunya belajar dan memperoleh pengetahuan. Guru yang empati dapat membayangan pikiran dan perasaan siswa menurut persepsi murid bukan menurut persepsi guru. Contohnya dalam kegiatan pembelajaran, guru yang empati merancang dan melaksanakan proses pembelajaran sesuai dengan situasi dan kondisi siswa, bukan sesuai dengan situasi dan kondisi guru. Hal ini dapat dilihat dari bahasa yang digunakan dan cara guru memperlakukan siswa.

Empati yang dimiliki seseorang sangat penting untuk membentuk karakter yang kuat, apabila seseorang telah memiliki empati, ia akan menjadi care terhadap siapapun, tidak mau menyakiti orang lain, dan selalu berusaha berbuat baik. Apabila rasa empati sudah tumbuh dapat menggerakkan orang lain juga untuk bersikap empati. Empati juga dapat malahirkan kejujuran dalam menghadapi dilema moral. 


\section{f. Menarik}

Penampilan memainkan peranan penting dalam membentuk kepribadian guru, Guru perlu menampilkan diri dengan ciri-ciri yang dapat diteladani seperti: pemilihan pakaian, hendaknya memilih warna yang menarik dan tidak menyolok, make up yang sederhana bagi wanita, kebersihan tubuh, perhiasan, kerapian, penggunaan minyak wangi, dan gaya rambut, semua itu menjadi contoh model bagi para pelajar.

Cara berpakaian guru dalam penampilann menunjukkan sikap dan kepribadiannya. Setiap guru mengajarkan tentang cara berpakaian, di saat itulah guru harus berpenampilan sebagaimana layaknya seorang guru. Mulai dari ujung rambut dan ujung kaki siswa selalu memperhatikan penampilan guru. Apakah rambutnya tersisir rapi atau berantakan, baju dan celana kusut, dan sepatu kusam semua ini menjadi perhatian murid.

Cara duduk guru pun menjadi perhatian siswa. Duduk dalam keadaan tegak maupun condong sedikit kehadapan murid menunjukkan guru yang berminat terhadap muridnya. Guru yang duduknya terlalu menyandar di kursi menunjukkan guru kurang berminat dalam mengajar. Sebaiknya guru dalam keadaan posisi berdiri dalam mengajar karena dapat melihat semua perilaku murid di dalam kelas.

\section{g. Fungsi Guru sebagai Pelopor Pembaharuan}

Guru sebagai figur masa kini dituntut memiliki visi dan misi yang berwawasan masa depan. Upaya untuk mengimplementasikan pendidikan yang berwawasan masa depan, peran guru tidak boleh dipandang sebelah mata, guru harus diberi keleluasaan, dan kebebasan untuk mengelola secara kreatif, liar, dan mencerdaskan sehingga proses belajar mengajar berlangsung menarik, aktif, efektif, dan menyenangkan. Profesi guru sangat penting dan menentukan bagi masa depan bangsa, oleh karenanya guru harus memiliki jati diri yang kuat, menjadi teladan, merencanakan dan melaksanakan proses belajar mengajar dengan penuh gairah dan hati yang tulus. Peserta didik juga harus memiliki cara pandang baru, bahwa sekolah bukan merupakan keharusan tetapi merupakan kebutuhan. Siswa bukan peserta yang pasif tetapi harus aktif, siswa bukan tidak berdaya tetapi memiliki kekutan untuk mencapai apa yang diinginkannya hanya kurang dimotivasi saja oleh guru. Sosok guru yang memiliki visi dan misi yang berwawasan masa depan memiliki karakteristik sebagai berikut: 


\section{1) Memiliki Komitmen}

Komitmen yang ditunjukkan guru tentu saja profesi dan tugasnya sebagai seorang pendidik. Guru yang memiliki komitmen selalu menjaga etika guru, mementingkan tugas pokoknya, selalu berupaya meningkatkan pengetahuannya, membangun integritas, dan selalu berusaha menjadi lebih baik dan dapat mengatasi tantangan yang terjadi dalam melaksanakan tugasnya.

Menurut Rosyid (2012), uraian dari undang-undang di atas mengimplikasikan bahwa, "guru tidak lagi berperan sebagai piranti negara yang semata-mata mengabdi kepada kepentingan pemerintah atau penguasa, tetapi sebagai hamba kemanusiaan, yang mengabdikan diri untuk memanusiakan generasi bangsa secara utuh dan paripurna (cerdas intelektualnya, emosinya dan spiritualnya)."

\section{2) Memiliki Semangat yang Tinggi dalam Bekerja}

Guru harus memiliki semangat kerja tinggi sehingga tujuan pembelajaran yang telah ditentukan sebelumnya tercapai dengan baik. Menurut Bafadal (2004:92), "seorang guru yang memiliki semangat atau moral kerja yang tinggi akan bekerja dengan penuh antusias, bergairah, berinisiatif, merasa gembira, merasa tenang, memiliki ketelitian, suka bekerjasama, ulet, tabah, dan tidak pernah datang terlambat." Selanjutnya dikatakan pula, "guru yang memiliki semangat kerja yang rendah tampak kurang bergairah, malas, suka melamun, sering terlambat bahkan tidak masuk kerja sering mengganggu, menyendiri, dan suka membuat kesalahan." Manivestasi dari semangat kerja yang tinggi adalah aktif, bertanggungjawab, rajin, dan terdorong untuk menjadi yang terbaik dalam berpartisipasi untuk memajukan organisasinya.

\section{3) Mengembangkan Kemampuan Diri Secara Bersama-sama}

Guru merupakan salah satu profesi yang ada di masyarakat yang berperan menyelenggarakan proses belajar mengajar untuk mencapai tujuan pendidikan. Sebagaimana profesi yang lain, profesi guru sifatnya juga kompetitif, baik sesama profesi maupun dengan profesi lain yang ada di masyarakat. Sebuah profesi tanpa kompetisi, tidak akan dapat bertahan dan bahkan lama-lama akan mati. Jika profesi guru tidak kompetitif maka lamalama akan hilang dari peredaran, padahal peran guru sangat dibutuhkan untuk mencapai masyarakat yang maju, melek teknologi, berkepribadian dan profesional.

Guru dituntut selalu up to date, menguasai teknologi dan kemajuan informasi, sehingga dapat menyesuaikan diri dengan kebutuhan peserta 
didiknya. Apabila guru tidak menguasai teknologi dan kemajuan informasi, tentu saja guru tidak dapat membimbing dan membantu siswanya untuk memperoleh perkembangan ilmu pengetahuan dan teknologi yang semakin berkembang. Pengembangan diri guru sebagai profesional juga harus dapat membantu pengembangan kepribadian guru agar lebih matang karena dengan penguasaan ilmu dan teknologi disertai dengan kepribadian yang prima akan menghasilkan peserta didik yang terampil dalam ilmu dan teknologi serta dapat menghadapi tantangan di masa depan.

Rumusan kode etik kongres Persatuan Guru Republik Indonesia (PGRI) XIII tanggal 21 sampai 25 November 1973, salah satu butirnya menyebutkan bahwa guru menciptakan dan memelihara hubungan antara sesama guru, baik berdasarkan lingkungan kerja maupun dalam hubungan keseluruhan. Butir ini menuntut guru memiliki kepribadian dewasa yang meliputi kemampuan menerima kritik, kemampuan dan kemauan memberikan saran dan sabar. Seorang guru yang menerima kritik dengan sabar akan semakin dewasa dalam pola berpikir, seperti diungkapkan oleh Gordon dalam Suparji, (2009) bahwa "sikap menerima dengan ikhlas adalah faktor penting dalam membantu mengembangkan kemudahan pemecahan masalah, mengembangkan perubahan konstruktif dalam mendorong usahausaha menuju sikap produktif." Terkait dengan hal ini Muhson (2004:95), mengemukakan: "Guru sendiri harus mau membuat penilaian atas kinerjanya sendiri atau mau melakukan otokritik di samping harus pula memperhatikan berbagai pendapat dan harapan masyarakat."

\section{4) Modern, Informatif dan Komunikatif}

Pada setiap kegiatan pembelajaran diharapkan bahwa komunikassi antar pribadi hendaknya berlangsung setiap saat. Mulyana (1999:5) menjelaskan, "kemajuan teknologi tidak otomatis membuat komunikasi antar pribadi diabaikan bahkan ditinggalkan karena bentuk komunikasi inilah yang dapat menimbulkan keakraban dan kehangatan antara guru dengan siswa." Komunikasi ini terjadi antara guru dan siswa atau antara siswa dengan siswa. Efektif tidaknya suatu komunikasi sangat ditentukan oleh kedua belah pihak, tetapi karena dalam pembelajaran guru merupakan kuncinya maka tejadinya komunikasi yang efektif sangat tergantung dari kerpibadian guru.

Banyak ditemui kasus seorang guru yang terampil secara pedagogis dan profesional dalam mata pelajaran tertentu, tetapi tidak disenangi oleh muridnya bahkan hasil pembelajarannya tidak memuaskan. Masalah ini dapat timbul disebabkan tidak adanya hubungan yang baik antara guru dengan peserta didik, baik di kelas maupun di luar kelas. 
Kompetensi kepribadian memberikan gambaran kemampuan guru sebagai seseorang yang bertindak sesuai dengan norma agama, hukum, sosial, dan kebudayaan nasional Indonesia. Seorang guru harus dapat menghargai peserta didik tanpa membedakan keyakinan yang dianut, suku, adat-istiadat, daerah asal, dan gender. Bersikap sesuai dengan norma agama yang dianut, hukum dan norma sosial yang berlaku dalam masyarakat, serta kebudayaan Nasional Indonesia yang beragam.

\section{Kesimpulan}

Pencapaian tujuan pembelajaran serta keberhasilan dalam berbagai masalah pembelajaran banyak tergantung pada kemampuan atau kompetensi guru. Guru yang memiliki kepribadian tentu akan menjadi harapan semua peserta didik, agar pendidikan ini tampil sesuai dengan apa yang dicitacitakan. Guru yang berkepribadian harus menjadi cita-cita semua guru di sekolah agar dunia pendidikan tidak kalah bersaing dalam era globalisasi. Oleh karena itu, untuk menjadi guru yang berkepribadian, mulailah dari diri sendiri, mulailah dari hal yang kecil, mulailah banyak memberi, dan mulailah menata diri sendiri.

\section{Daftar Pustaka}

Bavadal. (2004). Peningkatan Profesional Guru, S. Jakarta: Bumi Aksara

Cooper, J. M. (1986). Clssroom Teaching Skills (3rd). Stok, Boston:D.C. Heath and Company.

Goncsi, A. (2004). The New Profesional and Vocational Education. Crows Nest NSW:Allen \&Unwin

Hakim, M. L. (2012).”The Great Teacher: Mendedah Aspek-aspek Kepribadian Guru Ideal dan Pembentukan Perilaku Siswa dalam Novel Pertemuan Dua Hati Karya NH.Dini.Jurnal Pendidikan Dompet Duafa. 2, (1), 1-12.

Irsyad, M. (2008). Guru dituntut Guru Menuntut. Jurnal Alternatif Pendidikan Insania. 13, (2), 189-202

Kusnandar. (2007). Guru Profesional: Implementasi Kurikulum Tingkat Satuan Pendidikan dan Sukses dalam Sertifikasi. Jakarta: Raja Grafindo Persada.

Majid, A. (2005). Perencanaan Pembelajaran: Mengembangkan Standar Kompetensi Guru. Bandung: PT Remaja Rosdakarya. 
Manurung, R, T. (2008). Terhempasnya Wibawa Guru: Suatu Kajian Kontrastif Karya Sastra Masa Kini dan Masa Lalu., Jurnal Sosio Teknologi, 15, (7), 510-511.

Metro. (2010). Oknum Guru SD Melakukan Pelecehan Seksual. 20 Juli 2010.Pontianak.

Mouly, G. J. (1973). Psychology for Effective Teaching (3rd ed.). New York: Holt, Rinehart \& Winston.

Mulyana, R. (2001). Profil Kepribadian Guru Dalam Dimensi Psikhologis, Sosial, dan Spiritual, Desertasi UPI Bandung: Tidak diterbitkan.

Mulyasa, E. (2003). Standar Kompetensi dan sertifikasi Guru. Bandung: Remaja Rosdakarya.

Rastodio. (2009). [Online]. Kinerja Mengajar Guru. Tersedia: http://rastodio.com /pendidikan/mengukur-kinerja-mengajarguru.html. [20 April 2010].

Rosyid, Rum. (2012). [Online]. Guru sebagai agen Perubahan.Tersedia: http://www. scribd.Com/doc/37414812/ Guru-Sebagai-AgenPerubahan diakses 13 januari 2012.

Rusman, (2010). Model-Model Pembelajaran: Mengembangkan Profesionalisme Guru. Jakarta. Rajawali Pers.

Simbolon, M. (2008). "Persepsi dan Kepribadian. "Jurnal Ekonomi dan Bisnis" 2, (1), (52-66).

Slavin. (1995). Cooperative Learning Theory. Second Edition. Massachusetts: Allyn and Bacon.

Suparji. (2009). [Online]. "Pengembangan Instrumen Kompetensi Kepribadian Mahasiswa Calon Guru”. Jurnal Varia Pendidikan. 21, (1), 30-39. Tersedia: eprints.ums.ac.id/1711/1/4._SUPARJI.pdf. Diakses 23 April 2009.

Supriadi, D. (2007). Mengangkat Citra dan Martabat Guru. Yogyakarta: Adicita Karya Nusantara.

Surya, M. (2003). Percikan Perjuangan Guru. Semarang: CV Aneka Ilmu.

Syah, M. (2005). Psikologi pendidikan dengan pendekatan baru. Bandung: Remaja Rosdakarya.

Tilaar, H. A. R. (1999). Beberapa Agenda Reformasi Pendidikan Nasional Dalam Perspektif Abad 21. Magelang: Penerbit Tera Indonesia.

Uno. H, B. (2007). Profesi Kependidikan. Jakarta: PT. Bumi AksaraUzer. 